\title{
AUTHORITARIAN \\ RESPONSES TO FOREIGN PRESSURE: \\ Spending, Repression, and Sanctions
}

Abel Escribà-Folch

$2009 / 21$

$$
\begin{aligned}
& \begin{array}{|l|l|l|}
\hline \text { I } & \text { B } \\
\hline & \text { E } & \text { I } \\
\hline
\end{array} \\
& \text { INSTITUT } \\
& \begin{array}{l}
\text { BAREELTDIS } \\
\text { DNERNACIONALS }
\end{array}
\end{aligned}
$$

\section{Abel Escribà-Folch}

Institut Barcelona d'Estudis Internacionals (IBEI) aescriba@ibei.org 


\section{IBEI WORKING PAPERS}

$2009 / 21$

Authoritarian Responses to Foreign Pressure: Spending,

Repression, and Sanctions

(C) Abel Escribà-Folch

(C) IBEI, de esta edición

$\begin{array}{ll}\text { Edita: } & \text { CIDOB edicions } \\ & \text { Elisabets, } 12 \\ & 08001 \text { Barcelona } \\ \text { Tel. } 933026495 \\ \text { Fax. } 933022118 \\ \text { E-mail: publicaciones@cidob.org } \\ \text { URL: www.cidob.org }\end{array}$

Depósito legal: B-21.147-2006

ISSN:1886-2802

Imprime: Color Marfil, S.L.

Barcelona, August 2009 


\title{
AUTHORITARIAN RESPONSES TO FOREIGN PRESSURE: SPENDING, REPRESSION, AND SANCTIONS
}

\begin{abstract}
Abel Escribà-Folch
Abstract: This paper explores how international sanctions affect authoritarian rulers' decisions concerning repression and public spending composition, and how different authoritarian rulers respond to foreign pressure. If sanctions are assumed to increase the price of loyalty to the regime, then rulers whose budgets are not severely constrained by sanctions will tend to increase spending in those categories that most benefit their core support groups. In contrast, when constraints are severe due to reduced aid and trade, dictators are expected to greatly increase their levels of repression. Using data on regime types, public expenditures and spending composition (1970-2000) as well as on repression levels (1976-2001), we show that the empirical patterns conform well to our theoretical expectations. Single-party regimes, when targeted by sanctions, increase spending on subsidies and transfers which largely benefit more substantial sectors of the population and especially the urban classes. Likewise, military regimes increase their expenditures on goods and services, which include military equipment and soldiers' and officers' wages. Conversely, personalist regimes reduce spending in all categories, especially capital expenditures, while increasing repression much more than other regime types when targeted by sanctions.
\end{abstract}

Key words: Authoritarian Regimes, Sanctions, Public Spending, Repression, Survival, Foreign Pressure.

Acknowledgements: The author wishes to thank Joseph Wright, Alexander Debs, and one anonymous reviewer for their useful comments and suggestions. 


\section{Introduction}

Many studies have offered responses to the question of why international sanctions seem more often to fail than to succeed. ${ }^{1}$ Saddam Hussein's regime in Iraq, Castro's Cuba and the military junta in Burma are significant instances where foreign coercion has failed to destabilize incumbent regimes or produce any significant change in their policies. Quite commonly, governments are treated simply as actors interacting with foreign governments (or international organizations) that calculate the costs of sanction episodes and on this basis decide whether to make concessions (Tsebelis, 1990; Drezner, 1998; Lacy and Niou, 2004). Yet governments targeted by sanctions need also to respond domestically to such episodes of pressure because this pressure may destabilize their rule from the inside as well (Kaempfer et al., 2004; Allen, 2008). The international dimension of such measures has been stressed at the expense of other consequences at the domestic level, other than known humanitarian impacts (Weiss et al., 1997).

For instance, with the aim of improving the human rights situation and fostering regime liberalization in Togo, governed since 1967 by Eyadema's personalist regime, the European Community, France, Germany and the US suspended aid to the country in the early 1990s. The annual average cost of these sanctions amounted to about $\$ 57$ million, according to Hufbauer et al. (2007). Aid as a percentage of Togo's GNI quickly shrank from more than 13 percent in 1992 to about 8 percent in 1993. Tax revenues, being extremely dependent on taxes on international trade, sharply decreased too, so the regime found it more and more difficult to buy off the support of core groups. Consequently, in 1993 repression levels doubled rapidly from 2 to 4 (on a scale ranging from 1 to 5,5 being the maximum level of terror). Repression declined to level 2 after France decided to resume aid to Togo in 1994, and increased to 4 when aid levels fell again in 1997-98. In sharp contrast, the imposition of sanctions did not cause a dramatic increase in repression levels in Chile under Pinochet's rule or in Burma under Saw Maung and Than Shwe. In these cases terror scale levels were already extremely high, and sanctions brought about either no increase or only minor and temporary ones.

Foreign pressure against an authoritarian regime or ruler is likely to trigger a response if the regime or ruler wishes to remain in power (Gershenson and Grossman, 2001). Indeed, Peksen (2009) and Wood (2008) find that sanctions lead governments to commit more human rights violations and to increase repression. However, while Peksen does not consider interaction between sanctions and political regimes, in Wood's contribution the distinction between democracies and dictatorships and the interaction with the sanctions dummy add little information as no significant differences between regimes are found.

1. According to estimates by Hufbauer et al. (2007), the success rate of sanctions is only about 34 percent. See Pape (1997) for a much more pessimistic figure. 
This paper focuses precisely on how the response to sanctions varies across authoritarian regime types. As repression is just one of the policy options dictators can resort to in order to maintain regime stability, the paper expands the range of policy options in response to foreign coercion by analysing also public spending and its composition. Concretely, we argue that the relation between sanctions and strategic responses is mediated by the regime type prevailing in the target country. Using data on regime types, on public expenditures (1970-2000) as well as on repression levels (1976-2001), we show that the empirical patterns conform well to our theoretical expectations. Personalist rulers are found to respond with the highest increases in repression due to their inability to increase government spending. In contrast, singleparty as well as military regimes are able to increase the benefits they bestow on their support groups.

The remainder of the paper proceeds as follows. The second section briefly reviews the literature on the survival of authoritarian regimes and the strategies they use to retain power. The third section further details and discusses the differences between regime types. The fourth section develops a simple framework to help explain the options available to dictators when they are targeted by sanctions, and the possible scenarios these coercive episodes may generate concerning public revenues. The fifth section describes the variables, data, and methods employed in this study. In the sixth section we present and discuss the results of the empirical analyses. The final section summarizes the main findings.

\section{Authoritarian Regimes and Survival}

Dictatorships are generally viewed as characterized basically by the use of repression as the main means of retaining power. Yet recent contributions to the study of authoritarian rule have stressed that two strategies actually coexist in equilibrium, namely, repression and loyalty (Wintrobe, 1990, 1998; Gershenson and Grossman, 2001; Gandhi and Przeworski, 2006; Desai et al., 2009). According to Wintrobe, "the dictator who wishes to remain in office therefore faces a trade-off between these two alternatives" (1998: 46). The building of a support coalition and the co-optation of potential challengers are thus as important as the use of coercion. "Dictatorial regimes are therefore said to rely on an 'authoritarian bargain'" (Desai et al., 2009: 1).

Such a bargain is based on the delivery of different types of goods to elites and citizens depending on how great the need for loyalty is (Bueno de Mesquita et al., 2003), as well as on the granting of policy concessions (Gibson and Hoffman, 2002). The size of the support coalition is said to depend on the availability of rents and the strength of the initial opposition (Smith, 2005; Gandhi and Przeworski, 2006). As the size of the power coalition varies, so does the nature of the benefits distributed, according to Bueno de Mesquita et al. (2003). Specifically, these authors distinguish between private and public goods in order to account for political survival. Private 
goods (namely, access to graft, targeted transfers, and patronage) are allocated exclusively to members of the elite when it is relatively small, whereas public goods (public policies and spending) are delivered to all citizens or to a broad cross-section of them as the coalition expands.

A rent-delivery strategy is more easily pursued when resources that do not require costly extraction or citizens' cooperation (like income taxes) abound. Accordingly, natural resource endowments are generally found to lengthen the duration of authoritarian regimes (Smith, 2004; Ulfelder, 2007). When such windfalls are not available, dictators tend to resort to seemingly democratic institutions to mobilize support and offer limited political influence and representation to opposition groups. Gandhi and Przeworski $(2006,2007)$ argue that policy concessions require a formal institutional setting in order to provide them with credibility. Accordingly, they show that the number of parties within a legislature has a positive impact on dictators' stability in power.

\section{Regimes, Elites and Support Groups}

In this paper we depart from Geddes' (1999) classification of authoritarian regimes, which distinguishes personalist, single-party and military regimes. In her own words,

Different kinds of authoritarianism differ from each other as much as they differ from democracy. Their leaders emerge from different groups and via different selection processes. They rely on different segments of society for support. They have different procedures for making decisions, and different interest groups influence policies. Intra-elite factionalism and competition take different forms in different kinds of dictatorship, and consequently succession occurs in different ways. They deal with ordinary citizens and opposition in different ways. (Geddes, 2004: 5)

Personalist regimes include well-known cases like Zaire under Mobutu's rule, Trujillo's regime in the Dominican Republic and the aforementioned Etienne Eyadema's regime in Togo. Single-party regimes include, for example, the PRI regime in Mexico, East European socialist systems, the MPLA regime in Angola, Guinea under the Democratic Party of Guinea, Kenya under the KANU, and Tunisia under the Socialist Destourian Party (now called the Constitutional Democratic Rally). Finally, examples of military regime include Argentina's highly repressive juntas in the late 1960s and 70s, Brazil's governments in the 1960s and 70s, and Park Chung-Hee's regime in South Korea.

Military regimes stand apart from other types of authoritarian regime because the key priority of military elites is not necessarily to maximize the duration of their 
stay in power. In military regimes, "because most officers value the unity and capacity of the military institution more than they value holding office, they cling less tightly to power than do office holders in other forms of authoritarianism" (Geddes, 2004: 26). Conversely, in single-party regimes all factions within the regime have incentives to cooperate with the aim of remaining in office. Furthermore, party organizations, as noted above, provide party members with a durable framework wherein to resolve differences, bargain and advance their influence. As a result, dominant party systems generate and maintain a cohesive leadership cadre (Brownlee 2007; Smith, 2005). Under personalist regimes, rival factions will remain loyal only if the pay-off from supporting the ruler exceeds the expected benefits of risky opposition, since "in contrast to single-party regimes, the leader's faction in a personalist regime may actually increase benefits to itself by excluding the rival faction from participation" (Geddes, 2004: 14).

The reliance on different groups for support is likely to shape the public spending priorities of each type of regime. Military regimes care principally about the cohesiveness and status of the armed forces (Geddes, 1999). Holding the coalition together involves, in this case, serving the corporate interests of the army by, fundamentally, keeping the military budget high, paying decent wages to officers and getting good "state of the art" military equipment: in other words, devoting a significant amount of public resources to goods and services or military expenditures. Indeed, Collier and Hoeffler (2007) find that a high risk of a coup d'état results in more military spending used to buy off the military.

Single-party regimes have larger winning coalitions and are hence more prone the deliver public goods to their key constituencies. The party organization claims to represent the will of the people or of some broad section of the society (such as the working class under Communist regimes). "This claim renders single-party regimes vulnerable to contentious collective action because virtually any mass mobilization can be construed as a blow to the legitimacy of the regime" (Ulfelder, 2005: 317). The emergence of such regimes, often endorsing socialism, usually means the expansion of public services and redistributive transfers which tend to favour the urban classes. Indeed, single-party systems are the regime type devoting the highest percentage of its expenditures to subsidies and transfers. ${ }^{2}$

Under personalism, according to Jackson and Rosberg (1984: 424), "the system favours the ruler and his allies and clients: its essential activity involves gaining access to a personal regime's patronage or displacing the ruler and perhaps his regime and installing another". The support group in this case comprises a reduced set of individuals with family, ethnic or clan ties to the leader. A combination of rent distribution, sanctions and rotation characterizes the maintenance of a steady degree of 2. Concretely, 21 percent of total expenditure; while personalist regimes spend on average only 13 percent of expenditures on this category, and military
regimes 19 percent. 
loyalty from within the elites aimed at thwarting palace putsches and plots. The rest of the population remain true outsiders to the political process and its associated benefits, and are rendered subject to poverty, repression and de-mobilization. This logic of buying off support through patronage renders rulers dependent on the capture of windfalls and the fungibility of foreign aid so that they can be used to fund government consumption. ${ }^{3}$

\section{Responses to Economic Coercion and Regime} Type

Economic sanctions consist of the imposition of coercive measures with the aim of bringing about a policy or institutional change in the target country or of destabilizing the incumbent regime. Kaempfer et al. (2004) find that in 200185 percent of US unilateral sanctions targets were countries rated by Freedom House as "not free" or "partly free". Much of the literature on the effectiveness of sanctions finds the costs to the target to be one of the main determinants of the success of sanction episodes (Hufbauer et al., 2007; Dashti-Gibson et al., 1997; Drury, 1998; Nooruddin, 2002). Theoretical contributions from the public choice approach have added relevant insights to this general finding by paying attention to cost allocation and the political economy of political support. Thus, Kaempfer and Lowenberg (1988: 792) argue that "the sanctions which are most likely to precipitate the desired political change in the target country are those which concentrate income losses on groups benefiting from the target government's policy". Similarly, Kirshner (1997) claims that for sanctions to be effective they should target either the central government or the core groups whose support is essential for the regime to remain in power. In this paper, we explore some of the conditions under which these two latter claims might be true. The first question to be answered is, then, which leaders/regimes are the most sensitive to external revenue losses? And second, how do they react to such constraints?

Concerning the consequences of sanctions under non-democracy, Kaempfer et al. (2004), departing from Wintrobe's (1998) well-known model, assume that sanctions make the dictator's budget expand (as he is able to capture the rents associated with trade restrictions) and hence focus on the effect of sanctions on the level of opposition to the regime. According to them, if sanctions increase the capacity of the opposition, they may reduce the budget of the dictator and increase the price of repression. Increasing the price of repression means that it is more costly for the dictator to pursue repression against the opposition as a means of increasing his power. If in addition

3. Indeed, average government consumption of goods and services as a percentage of GDP is higher under personalist regimes than under the other two regime types. Concretely, it is 15.73 percent for personalist regimes, 12.60 percent for single-party systems, and 12 percent for military regimes. 
the price of loyalty rises, the power of the dictator will be reduced. ${ }^{4}$ In contrast, in a second scenario, if sanctions have little effect on the strength of the opposition, and if in addition the price of loyalty decreases, then an authoritarian ruler's levels of repression, loyalty and, hence, power would rise. ${ }^{5}$ If the price of loyalty rises, repression would increase, but the ruler's overall level of power would probably remain unaffected. In a much simpler setting which considers the effect of foreign pressure on the elite's probability of remaining in power, Gershenson and Grossman (2001) show that an increase in such pressure would (ideally) lead the ruling elite to raise the levels of both repression and co-optation as an optimal response.

At the empirical level, some recent research has started to explore the domestic consequences of coercion for the target countries. It is well known that sanctions have had important humanitarian impacts on the target countries' populations (Weiss et al., 1997). Yet the domestic political and economic costs (in terms of policy changes) have received much less attention. But a few recent examples of such studies exist. Allen (2008) shows that sanctions boost anti-government activity in the target countries, especially under more democratic settings. Accordingly, Peksen (2009) and Wood (2008) find that sanctions lead governments to commit more human rights violations and to increase repression. However, as remarked in the introduction, while Peksen does not consider any possible variation across political regimes (democracy vs. dictatorship), in Wood's contribution the distinction between democracies and dictatorships and the interaction with the sanctions dummy add little information as levels of repression are found to increase only slightly - and not significantly - more under dictatorships. Nevertheless, as noted earlier, there also exist profound differences in the way authoritarian regimes work, differences which we will exploit to further understand authoritarian reactions to sanctions.

We assume that dictators are rational and self-interested actors who want to maximize their probability of remaining in power. The optimal response, then, to international sanctions will largely vary according to the regimes' relative capacity to vary the levels of loyalty and repression in reaction to changes in their respective prices and the size of the budgetary constraints imposed by economic sanctions. If we take this last statement as an initial assumption, variation in the responses of autocrats will fundamentally hinge on how constraining sanctions are in terms of government revenues, too. Some important studies take it for granted that the scarcity and the alteration in the terms of trade that sanctions cause generate rents that dictators are able to capture (Kaempfer et al., 2004; Lektzian and Souva, 2007). If that is the case, sanctions would potentially improve rulers' capacity to buy off political support and so increase public expenditures. Again, though, homogeneity across regime types is generally assumed. Moreover, this general assumption, in my opinion, relies too much on the Iraqi case during the 1990s, when, according to the Independent Inquiry Committee (IIC) into the United Nations Oil-for-Food Programme (OFFP), Hussein's 
regime managed to earn over \$11 billion from illicit oil sales during 1990-2003. An estimated $\$ 1.8$ billion was earned from kickbacks and surcharges on OFFP contracts and sales. But this case appears to be exceptional. Both financial sanctions and trade restrictions affect some of the principal sources of revenue and windfalls of authoritarian regimes, namely, foreign aid, taxes on international trade and non-tax revenues (Bates, 2008), which commonly serve to fund rulers' deep patronage networks. Developing countries are usually extremely dependent on a few revenue streams (aid, for example) for which there is no easy substitute in the short term. Therefore, in the empirical section, we will first examine whether sanctions cause different levels of revenue loss across regime types.

The amount of transfers and repression delivered depends on the level of support the government enjoys. Sanctions are assumed simply to diminish such support, as remarked earlier, so without a response from the regime the new situation would involve a decrease in the leaders' security levels. The empirical findings summarized above (increased protests and terror) indicate that the imposition of international sanctions indeed tends to increase the prices of loyalty and repression. The reasons for this increase vary, since sanctions increase autocrats' perception of threats both from the supporting coalition and from other sources.

As for members of elites, economic coercion may induce a change in the preferences of key actors and the distribution of power within the regime, provoking, as a result, defections from the ruling coalition and the realignment of other supporting groups (Olson, 1979; Gleditsch and Ward, 2006). As for the opposition, sanctions can be interpreted as a signal that foreign countries are backing its demands (Kaempfer and Lowenberg, 1992), so they may bolster the opposition's resolve to continue organizing and challenging the incumbent regime. It is less likely, but still possible, that opposition groups may benefit from sanctions through cross-border smuggling and black markets. Yet the main mechanism for fostering opposition to the regime is generally thought to be economic deprivation. Economic scarcity caused by foreign coercion may spur collective action and political contestation against the incumbent regime due to increased poverty, inflation and inequality, especially as dictators will try to move the costs away from their core supporting elites (Niblock, 2001; Brooks, 2002; Allen, 2008).

Second, sanctions may also positively affect the price of loyalty. Specifically, economic sanctions may reduce the expected long-run benefits of political support for the incumbent regime. Doubts are likely to emerge concerning the regime's institutional stability and its future capacity to deliver rents and benefits. Faced with this scenario, and to avoid destabilization and maintain the pre-sanction level of security, authoritarian rulers must increase the levels of patronage and repression.

In sum, the optimal response to foreign pressure will be conditioned by how constraining sanctions are. If sanctions do not cause important revenue losses, the optimal response should be that stated above, namely, an increase in both patronage/ co-optation and repression (hypothesis 1). In contrast, if sanction episodes translate 
into a sharp decrease in external revenues, then the amount of patronage that the ruler can provide his supporters through the use of public expenditures and other privileges will shrink. Consequently, such dictators are left with just one option in order to retain power, namely, to substantially increase repression, since, as Wintrobe claims, "repression is variable in the short as well as the long-run" (1998: 47). External revenue - like aid, some forms of non-tax revenue or trade taxes - does not have an easy substitute. Increasing revenues is not feasible in the short term given the limited administrative capacity of many regimes (Escribà-Folch, 2009). In sum, a decrease in public expenditures will be accompanied by a substantial rise in repression levels (hypothesis 2).

\section{Empirics}

\subsection{Revenue Losses: Aid and Trade}

Sanction episodes translate into the disruption of financial and commercial flows between the sanctioning countries and the target country. In this section we explore, using very parsimonious models, whether these costs differ across the regime types considered: personalist, single-party, and military.

The conditional nature of our hypotheses requires the examination of the interactions between sanctions and authoritarian regime type. We use a dichotomous indicator of sanctions. The variable is taken from Marinov's (2005) update of the data used by Hufbauer et al., and can have two values: 1 if a country has been targeted by economic sanctions in a given year, 0 if not. The sanctions variable is generally lagged for one year. For dictatorial regimes, we use the typology developed by Geddes (1999, 2004), which has been recently extended and updated by Wright (2007). We have grouped the different regimes into three basic categories. First, we group monarchic and personalist regimes into a category named "personalist". The second category is "single-party" and comprises pure single-party types, single-party/personalist hybrids, single-party/military hybrids and "triple threat" regimes. ${ }^{6}$ Finally, the third category comprises military and military/personalist regimes.

Our dependent variables are the two main sources of external revenue affected by sanctions: foreign aid and trade. Aid is measured in dollars per capita and taken from the World Bank's World Development Indicators (WDI) for the period 1960-2000.

6. "Triple threats" are regimes that contain single-party, military and personalist characteristics. 
Trade, which is measured as the sum of imports and exports as a percentage of GDP, covers the period 1960-2000, and is also taken from the WDI. Both variables have been logged. Control variables include: the dependent variable lagged one year; oil and gas rents from Ross (2008); GDP per capita (logged) and total population (logged) from WDI and Maddison (2006), respectively; and a Cold War period dummy. For the aid models we have also included in an alternative specification two extra controls: a measure of how often the recipient country votes with the US in the UN General Assembly (US_agree) taken from Lebovic and Voeten (2009), and a War dummy indicating the presence of conflict as coded by Strand et al. (2005) at the International Peace Research Institute. ${ }^{7}$ Coefficients are estimated fixed-effects panel data models including a one-year lag of the dependent variable.

The results of these parsimonious models reported in Table 1 clearly show that the impact of sanctions is concentrated principally on personalist regimes, which are the reference category. ${ }^{8}$ The decreases are remarkably acute for the case of foreign aid. The bottom two rows report the net effect for single-party and military regimes. According to the estimates, the biggest decreases in aid and trade are concentrated among this type of regime, as their reliance on a few primary commodity exports (such as sugar in the Dominican Republic under Trujillo's regime, or coffee under Idi Amin's rule in Uganda) and external funds makes them particularly vulnerable.

7. A political terror measure was also included in the aid models to test whether donors tend to punish human rights violators, but it was not significant. The use of a one-year lag of the sanctions dummy yields very similar results for the foreign aid models. Concerning trade, lagging the sanctions variable shows that decreases in trade volume are slightly greater under military regimes than under personalist ones. 


\begin{tabular}{|c|c|c|c|}
\hline \multirow[b]{2}{*}{ Independent variables } & \multicolumn{2}{|c|}{ Log foreign aid (pc) } & \multirow{2}{*}{$\frac{\text { Log trade (\% of GDP) }}{(1)}$} \\
\hline & (1) & (2) & \\
\hline \multirow[t]{2}{*}{ Lagged dependent variable } & $0.719 * * *$ & $0.629 * * *$ & $0.775 * * *$ \\
\hline & $(0.013)$ & $(0.020)$ & $(0.013)$ \\
\hline \multirow[t]{2}{*}{ Sanctions } & $-0.202 * * *$ & $-0.216 * * *$ & $-0.041^{* *}$ \\
\hline & $(0.053)$ & $(0.060)$ & $(0.021)$ \\
\hline \multirow[t]{2}{*}{ Sanctions*Single-party } & $0.135^{* *}$ & 0.106 & 0.030 \\
\hline & $(0.067)$ & $(0.077)$ & $(0.026)$ \\
\hline \multirow[t]{2}{*}{ Sanctions*Military } & 0.116 & 0.148 & 0.011 \\
\hline & $(0.075)$ & $(0.094)$ & $(0.030)$ \\
\hline \multirow[t]{2}{*}{ Single-party regime } & 0.034 & -0.033 & 0.009 \\
\hline & $(0.041)$ & $(0.065)$ & $(0.017)$ \\
\hline \multirow[t]{2}{*}{ Military regime } & -0.015 & -0.056 & 0.004 \\
\hline & $(0.043)$ & $(0.059)$ & $(0.017)$ \\
\hline \multirow[t]{2}{*}{ GDP per capita (log) } & $-0.184 * * *$ & $-0.101 *$ & $0.030 * *$ \\
\hline & $(0.037)$ & $(0.054)$ & $(0.015)$ \\
\hline \multirow[t]{2}{*}{ Population (log) } & $-0.266 * *$ & $-0.629 * * *$ & $-0.120 * * *$ \\
\hline & $(0.116)$ & $(0.183)$ & $(0.042)$ \\
\hline \multirow[t]{2}{*}{ Oil rents } & -0.008 & -0.014 & $0.008^{*}$ \\
\hline & $(0.011)$ & $(0.021)$ & $(0.04)$ \\
\hline \multirow[t]{2}{*}{ Cold War } & $0.224 * * *$ & $-0.499 * * *$ & 0.013 \\
\hline & $(0.073)$ & $(0.146)$ & $(0.029)$ \\
\hline \multirow[t]{2}{*}{ US agree } & -- & $0.568^{*}$ & -- \\
\hline & & $(0.287)$ & \\
\hline \multirow[t]{2}{*}{ War } & -- & -0.003 & -- \\
\hline & & $(0.033)$ & \\
\hline $\mathrm{F}$ & 160.50 & 46.54 & 114.51 \\
\hline Observations & 2210 & 1461 & 2242 \\
\hline$\beta$ Sanctions $+\beta$ (Sanctions*Single-party) & -0.066 & $-0.110 * *$ & -0.011 \\
\hline$\beta$ Sanctions $+\beta$ (Sanctions*Military) & -0.085 & -0.068 & -0.030 \\
\hline
\end{tabular}


In practical terms, sanctions translate into sharp diminutions in personalist regimes' public revenues. Figure 1 illustrates this point by showing the average of the main components of public revenues as a percentage of GDP when the country is and is not under economic coercion for each regime type.

\section{Figure 1. Regimes, economic sanctions, and the composition of public rev- enues (\% of GDP)}

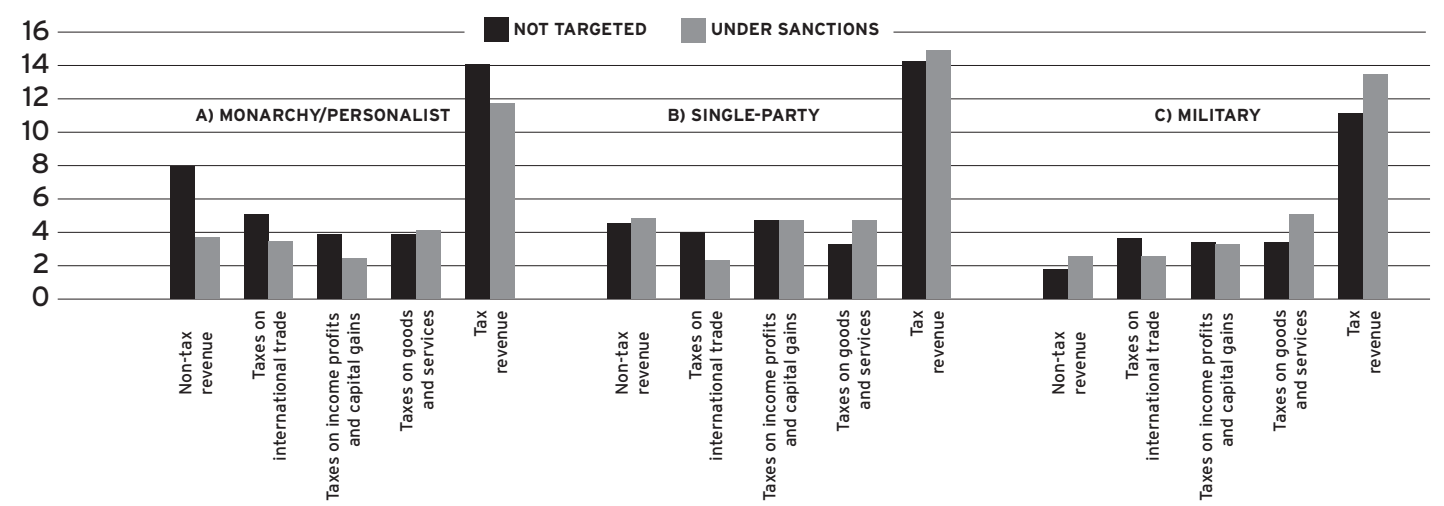

As is clearly shown, sanctions translate into much sharper budget constraints when targeting personalist regimes as they affect their three main revenue streams (see Figure 1.a): aid, non-tax revenues, and taxes on international trade. In contrast, single-party and military regimes are better able to shift fiscal pressure from one stream to another, so minimizing or cancelling out the impact of the cuts in some resource flows (principally, foreign aid) that sanctions bring about. In particular, the two regime types appear to be able to increase their non-tax revenues and taxes on goods and services. In light of this evidence, it is logical to expect sanctions to cause sharp decreases in public spending in personalist regimes and, at the same time, a greater increase in political terror levels in such regimes than in the other two.

\subsection{Dictatorial Responses: Expenditures and Repression}

We test our set of hypotheses concerning authoritarian responses using a data set that contains information on sanctions, public expenditure composition and repression under different types of authoritarian regime. The data on spending covers about 70 countries for the period 1970-2000, while the data on repression covers almost 90 countries for the period 1976-2001. The unit of analysis is the country-year in both cases.

We use several dependent variables. In our analyses of co-optation policy, we use data on public spending composition from the World Bank's WDI. Concretely, the three categories of spending (as percentages of GDP) are: i) capital expenditures, 
which include capital grants and spending to acquire fixed capital assets, land, intangible assets, government stocks, and non-military, non-financial assets; ii) subsidies and transfers, which include transfer payments to individuals (such as pensions and welfare), and subsidies to private and public enterprises; and iii) expenditures on goods and services, which include all government payments in exchange for goods and services including wages and salaries to employees. We also use a measure of total government expenditures as a percentage of the GDP.

Data on repression comes from Hafner-Burton and Tsutsui (2007), who combine information from different existing political terror scales. The scale ranges from 1 to 5 , where 5 is the maximum level of state violations of physical integrity rights. ${ }^{9}$

Our main independent variables are those detailed above, namely, sanctions, regime types, and their interaction. The control variables for the models on public expenditures are the following: In order to capture the social structure of the country and the demands of the domestic population we include the percentage of the total population living in urban areas as well as the age dependency ratio. ${ }^{10}$ As usual, we include the log of GDP per capita in the models to capture development and state capacity. Windfall availability and the potential presence of rentier economies are captured by the amount of oil resources using Ross's (2008) measure of oil rents in a given year. We also include a variable gauging the absolute size of the government's budget - namely, current revenue as a percentage of GDP - in order to control for fiscal constraints and scale effects (see Kenny and Winer, 2001). We also control for the levels of trade openness (sum of exports and imports as a percentage of GDP) and external dependence in the form of foreign aid per capita. ${ }^{11}$ Using broad cross-country samples, trade openness is usually found to be correlated with a larger public sector as governments tend to mitigate the negative consequences that integration may have on some sectors of society. ${ }^{12}$

As for the models predicting repression levels, the control variables considered follow the specifications found in previous articles containing multivariate analyses of human rights violations (Poe and Tate, 1994; Poe et al., 1999; Davenport, 2007; Wood, 2008). On the socioeconomic side, we include the log of the total population size, the percentage of urban population, the log of GDP per capita, and the rate of economic growth. ${ }^{13}$ Ethnic diversity is captured by the index of ethno-linguistic fractionalization. We also include a measure of the percentage of Muslims living in the country. Growth and development may represent a source of loyalty towards the regime; if so, repression can be decreased. A dummy for the Cold War period is included (coded 1 for all years prior to 1991). This variable permits

\footnotetext{
9. It includes "murder, torture, or other cruel, inhuman, or degrading treatment or punishment; prolonged detention without charges; disappearance or clandestine detention; and other flagrant violations of the right to life, liberty, and the security of the person" (Hafner-Burton, 2005: 615).

. These variables have been taken from the WDI. The age dependency ratio is calculated as the ratio of dependants, that is, the population under age 15 and above age 65 , to the working-age population.

1. These three variables (revenues, aid, and trade) are taken from WDI

2. See, for instance, Rodrik (1998).

3. To maximize the number of observations these variables are taken from Maddison's (2006) data set, which has the most extensive time-series economic data for authoritarian countries, particularly for the years before 1990 .
} 
us control for the Cold War policy of tolerance towards many repressive regimes due to strategic concerns and alignments. The new emphasis of the US and other Western countries after the end of the Cold War on human rights protection and democratization may have changed the incentives of authoritarian rulers to repress dissent. Yet, as some argue, it is precisely this international environment that may have led most dictatorial regimes to increase repression as foreign pressure for liberalization has abruptly increased. ${ }^{14}$ We also include a dummy variable coded 1 for every year in countries that became independent after 1945, 0 otherwise. Again, external dependence is captured by foreign aid per capita and trade openness, so they in a way help to control for the prior financial and commercial linkages with other countries. Following Wood (2008), in order to avoid autocorrelation with the lagged sanctions measure, we use a two-year lag of these two variables. To check the robustness of the results we also report a model including just a one-year lag of these two measures. Finally, we control for the presence of internationalized internal, just internal or interstate conflict using the International Peace Research Institute's conflict data set (version 3-2005). ${ }^{15}$ Wars constitute an important threat to regime stability, so it is likely that the regime responds to that threat with further repression (Poe et al., 1999).

The methodology adopted for the models on spending consists of a fixedeffects panel data estimator to control for unobserved heterogeneity. In order to tackle serial correlation we have run error correction models (ECMs), which can better deal with the dynamic structure of the data (De Boef and Keele, 2008). A common and concise way to report the results from ECMs is to calculate the total effect distributed over all time periods using the Bewley transformation, which allows estimating the long-run multiplier and its standard error. The model thus estimated has the following structure:

$$
Y_{t}=\phi_{0}-\phi_{1} \Delta Y_{t}+\psi_{0} X_{t}-\psi_{1} \Delta X_{t}+\mu_{t}
$$

So below I report only the result of the total effect using this transformation obtained by using instrumental-variable GMM models with fixed-effects in which the lagged dependent variable as well as contemporaneous values and changes of the Xs are used as instruments for the first difference of the dependent variable. All models include year dummies to control for exogenous shocks affecting all countries.

The models on repression are estimated using ordered logistic regressions. To control for autocorrelation in this case we include a series of binary indicators of a country's level of repression in the previous year, as the use of a lagged dependent variable might be problematic in nonlinear models (see Hafner-Burton, 2005). We use lagged values of our covariates and we cluster standard errors on the country in order to control for heteroskedasticity.

14. See Davenport (2007) for a discussion.

15. See Strand et al. (2005). 


\subsection{The Composition of Public Expenditures}

We begin with the analysis of expenditures patterns and the impact of sanctions under various forms of authoritarianism. The results of the estimations for all three spending categories and total expenditure are presented in Table 2.

The coefficient of the sanctions dummy indicates the effect of sanctions under personalist regimes (the reference category). Regarding the other two regime types, in the bottom two lines of the table we report the net effect of sanctions (resulting from the sum of the sanctions dummy alone and the interaction between sanctions and the corresponding regime dummy) and its level of statistical significance, if any.

The results confirm our initial intuitions and, hence, the proposed hypotheses. In short, Table 2 calls forth the following stylized patterns. First, most of the cuts induced by sanctions are concentrated in the capital expenditures category, especially under personalist regimes. The reason is simple. When survival is at stake, developmental concerns are clearly left aside in the event of binding budget constraints. This pattern has also been observed when other types of constraint are binding in less developed countries, such as economic crises (Van de Walle, 2001) or increasing debt burdens (Mahdavi, 2004). ${ }^{16}$

Second, economic sanctions are related to a severe retrenchment of the public sector in personalist regimes. Personalist regimes targeted by sanctions decrease their public expenditures by more than 4 points, mainly as a result of the severe cuts in their main sources of revenue that sanctions bring about, as shown above. This translates, as the other models show (1-3), into important cuts in all spending categories which seriously harm the capacity of these regimes to buy off political support. In clear contrast, single-party and military regimes tend to significantly increase public expenditures, thereby benefiting their main support groups and so seeking to cancel out the destabilizing impact of an increase in the price of loyalty that sanctions are likely to bring about. As noted above, single-party systems are the most likely to break down in the wake of contentious collective action (particularly strikes and anti-regime demonstrations) (Ulfelder, 2005). It makes sense, then, that single-party regimes, fearing that sanctions may unleash waves of mass dissent, choose to increase redistribution and spending that favour a substantial segment of the public. As Table 2 shows, sanctions indeed lead to a substantial increase in the resources single-party regimes devote to subsidies and transfers.

\footnotetext{
16. One then may wonder why the cuts are not much more severe, allowing the regime to reallocate most of those resources to other categories. Yet it is worth recalling that public investment is also used to buy off support from specific groups or constituencies by delivering targeted public goods (Bates, 2008), and that such expenditure has been found to be well correlated with corruption (Tanzi and Davoodi, 1997).
} 


\begin{tabular}{|c|c|c|c|c|}
\hline & $\begin{array}{l}\text { Subsidies and } \\
\text { transfers }\end{array}$ & $\begin{array}{l}\text { Goods and } \\
\text { services }\end{array}$ & $\begin{array}{c}\text { Capital } \\
\text { expenditure }\end{array}$ & $\begin{array}{c}\text { Total } \\
\text { expenditure }\end{array}$ \\
\hline Independent variables & (1) & (2) & (3) & (4) \\
\hline \multirow[t]{2}{*}{ Sanctions $_{t-1}$} & -1.48 & -1.69 & $-3.06 * * *$ & $-6.99 * *$ \\
\hline & $(0.964)$ & $(1.64)$ & $(1.16)$ & $(2.86)$ \\
\hline \multirow[t]{2}{*}{ Sanctions*Single-party } & $3.76^{* * *}$ & 1.74 & 2.20 & $7.34 * *$ \\
\hline & $(1.25)$ & (1.74) & (1.49) & (3.35) \\
\hline \multirow[t]{2}{*}{ Sanctions*Military } & 0.491 & $2.96 *$ & 1.90 & $6.18^{* *}$ \\
\hline & $(1.07)$ & $(1.62)$ & $(1.50)$ & $(2.90)$ \\
\hline \multirow[t]{2}{*}{ Single-party regime } & -1.33 & $2.77^{*}$ & -0.399 & 0.627 \\
\hline & $(1.02)$ & $(1.42)$ & $(1.56)$ & $(2.40)$ \\
\hline \multirow[t]{2}{*}{ Military regime } & -1.14 & $2.61^{* *}$ & -0.145 & 2.15 \\
\hline & $(0.745)$ & (1.03) & (1.21) & (2.05) \\
\hline \multirow[t]{2}{*}{ GDP per capita (log) } & $-1.76^{* *}$ & $-3.92 * * *$ & -0.399 & $-5.69 * *$ \\
\hline & $(0.866)$ & (1.14) & $(1.40)$ & (2.64) \\
\hline \multirow[t]{2}{*}{ Age dependency ratio } & 1.62 & -0.913 & $7.97^{*}$ & -0.659 \\
\hline & (3.14) & (3.82) & $(4.42)$ & $(9.06)$ \\
\hline \multirow[t]{2}{*}{ Urban population (\%) } & $0.059 *$ & 0.061 & $-0.114 *$ & -0.052 \\
\hline & $(0.035)$ & $(0.059)$ & $(0.065)$ & (0.108) \\
\hline \multirow[t]{2}{*}{ Foreign aid (log) } & -0.290 & 0.333 & $0.638 * *$ & $1.45^{* *}$ \\
\hline & $(0.210)$ & $(0.247)$ & $(0.297)$ & $(0.592)$ \\
\hline \multirow[t]{2}{*}{ Trade openness } & -0.012 & $-0.026 * *$ & 0.011 & -0.029 \\
\hline & $(0.010)$ & $(0.011)$ & $(0.012)$ & $(0.024)$ \\
\hline \multirow[t]{2}{*}{ Oil rents (log) } & 0.094 & -0.532 & -0.452 & $-1.42 *$ \\
\hline & $(0.290)$ & $(0.400)$ & $(0.423)$ & $(0.748)$ \\
\hline \multirow[t]{2}{*}{ Revenues } & $0.233 * * *$ & $0.410 * * *$ & $0.299 * * *$ & $0.962 * * *$ \\
\hline & $(0.051)$ & $(0.080)$ & $(0.059)$ & $(0.147)$ \\
\hline $\mathrm{F}$ & 1.46 & 2.47 & 3.10 & 2.99 \\
\hline Observations & 847 & 849 & 902 & 1007 \\
\hline$\beta$ Sanctions $+\beta$ (Sanctions*Single-party) & $2.27^{* * *}$ & 0.057 & -0.862 & 0.346 \\
\hline$\beta$ Sanctions+ $\beta$ (Sanctions*Military) & -0.995 & $1.28^{*}$ & -1.16 & -0.812 \\
\hline
\end{tabular}


Spending seems to be used to buy off support from the military, too (Collier and Hoeffler, 2007). Under military regimes it is spending on goods and services that is substantially (and significantly) augmented when the country is targeted by international sanctions. To further explore our proposition for the case of military regimes, we have two models using spending on wages and salaries (as a percentage of GDP) and military expenditures as dependent variables. ${ }^{17}$ The method employed is again an IV-GMM model using the Bewley transformation. Unfortunately, for military expenditures the series starts only in 1988, so one should be cautious when interpreting the results from such a limited number of observations. For the wages model, we use the same pool of control variables as in Table 2. As for military expenditures, we log the variable to reduce its scale and minimize the effect of some observed outliers. We include the log of the size of population. Given that military expenditures may be increased as a result of war, we use a measure of the intensity of any conflict in which the country may be involved. This is an ordinal variable from Gleditsch et al. (2002) that delineates three levels of conflict intensity: minor conflict $(<25$ deaths / year), intermediate conflict (<1000 deaths/year), and war ( $>1000$ deaths/year). As in the other models, we also control for foreign aid, trade openness, GDP per capita and the amount of oil rents accruing to the regime.

The results are reported in Table 3. As can be observed, the patterns we had already identified hold for both variables despite the variation in the number of observations and controls. Again, the bottom two rows report the net effect of sanctions under single-party and military regimes and its level of significance. The impact of economic sanctions on wages and salaries and on military expenditures under military regimes is positive and significant.

7. Military expenditures are measured as a percentage of GDP and taken from the Stockholm International Peace Research Institute databases (SIPRI) see http://www.sipri.org/contents/webmaster/databases. Military expenditures include personnel, operations and maintenance, procurement, military research and development, military construction and aid. I wish to thank SIPRI for sharing the data and Petter Stålenheim for sending them. 
Table 3. Wages and salaries, military expenditures, regimes and sanctions

\begin{tabular}{|c|c|c|}
\hline & Wages and salaries & Military expenditures \\
\hline Independent variables & (1) & $(2)$ \\
\hline \multirow[t]{2}{*}{ Sanctions $_{t-1}$} & $-2.94 * *$ & -0.067 \\
\hline & $(1.40)$ & $(0.078)$ \\
\hline \multirow[t]{2}{*}{ Sanctions*Single-party } & 2.03 & 0.071 \\
\hline & $(1.44)$ & $(0.127)$ \\
\hline \multirow[t]{2}{*}{ Sanctions*Military } & $4.41^{* * *}$ & $0.230 * *$ \\
\hline & $(1.52)$ & $(0.110)$ \\
\hline \multirow[t]{2}{*}{ Single-party regime } & $-2.57 * *$ & 0.234 \\
\hline & $(1.11)$ & $(0.204)$ \\
\hline \multirow[t]{2}{*}{ Military regime } & -0.092 & $0.280 *$ \\
\hline & $(1.16)$ & $(0.157)$ \\
\hline \multirow[t]{2}{*}{ GDP per capita (log) } & $-2.53 * * *$ & -0.134 \\
\hline & $(0.840)$ & $(0.142)$ \\
\hline \multirow[t]{2}{*}{ Foreign aid (log) } & -0.065 & $0.063^{* *}$ \\
\hline & $(0.198)$ & $(0.031)$ \\
\hline \multirow[t]{2}{*}{ Trade openness } & $-0.019 * * *$ & -0.0008 \\
\hline & $(0.006)$ & $(0.0009)$ \\
\hline \multirow[t]{2}{*}{ Oil rents $(\log )$} & $-0.767 * *$ & 0.030 \\
\hline & $(0.334)$ & $(0.045)$ \\
\hline \multirow[t]{2}{*}{ Urban population (\%) } & $0.106 * * *$ & -- \\
\hline & $(0.033)$ & \\
\hline \multirow[t]{2}{*}{ Age dependency ratio } & $-5.48 * *$ & -- \\
\hline & $(2.76)$ & \\
\hline \multirow[t]{2}{*}{ Revenues } & $0.081^{* * *}$ & -- \\
\hline & $(0.024)$ & \\
\hline \multirow[t]{2}{*}{ Population size } & -- & -0.506 \\
\hline & & $(0.332)$ \\
\hline \multirow[t]{2}{*}{ Conflict intensity } & -- & $0.131 * * *$ \\
\hline & & $(0.044)$ \\
\hline $\mathrm{F}$ & 1.81 & 3.08 \\
\hline Observations & 800 & 510 \\
\hline$\beta$ Sanctions $+\beta$ (Sanctions*Single-party) & -0.912 & 0.003 \\
\hline$\beta$ Sanctions $+\beta$ (Sanctions*Military) & $1.46^{*}$ & $0.163^{*}$ \\
\hline
\end{tabular}




\subsection{Repression}

Our hypothesis concerning the link between sanctions and repression claimed that repression levels will be increased to a greater extent by those regimes whose capacity to deliver goods, bribe and co-opt is most hurt by economic sanctions (see hypothesis 2).

Table 4 reports the results of the ordered logit estimations of repression levels in response to sanctions for different regime types. In model 1 there is no interaction between the sanctions dummy and the regime type variable. ${ }^{18}$ Model 2 incorporates such interaction. In model 3 we include a one-year lag instead of the two-year one for the variables measuring aid and trade. As it appears, sanctions have a strong and positive effect on repression levels. Yet, once the interactive terms are added, we can see that there exist significant differences between regimes in terms of repression as a response to economic coercion. As predicted, the highest increases are found in personalist regimes (see models 2 and 3). The impact of sanctions more than doubles (model 2 ) or almost doubles (model 3) under personal rule compared with single-party rule, and is about three (model 3) and four (model 2) times bigger than under military systems. According to the results in model 2, sanctions trigger a sharp increase in the probability of repression levels, being over 2 under personalist rule. For instance, the probability of repression being of level 3 increases from 0.60 to 0.62 when sanctions are imposed, that of being of level 4 from 0.09 to 0.23 , and that of being of maximum level 5 from 0.007 to 0.02 ; while to the likelihood of repression being at its lowest two levels ( 1 and 2 ) decreases. Thus, when the sanctions dummy changes from 0 to 1 , the likelihood of the repression level equaling 2 shrinks from 0.28 to just $0.11 .^{19}$

As the bottom two rows show, the increases in repression under the other two types of regime are much more moderate, although still significant for the case of single-party regimes. Again according to the estimates of model 2, the likelihood of level-3 repression increases from 0.58 to 0.63 , and that of level-4 repression rises from 0.07 to 0.11 . Average repression levels are already substantially higher under military regimes, ${ }^{20}$ so sanctions do not produce a considerable push in this case (the joint effect is not statistically significant; see bottom row).

\footnotetext{
18. We also ran models with further controls, such as oil rents, as it is often argued that oil revenues allow for a better and bigger repressive apparatus. Our measure of oil rents was not even close to significant in any specification, so it was ruled out.

19. In estimating all these probabilities the remaining variables have been held constant at their mean values.

20. Average political terror is 3.17 under military regimes, 2.79 under personal rule, and 2.76 under single-party regimes.
} 


\begin{tabular}{|c|c|c|c|}
\hline \multirow[b]{2}{*}{ Independent variables } & \multicolumn{3}{|c|}{ Political Terror Scale (1-5) } \\
\hline & (1) & $(2)$ & (3) \\
\hline \multirow{2}{*}{ Sanctions $_{\mathrm{t}-1}$} & $0.581^{* * *}$ & $1.15^{* * *}$ & $1.14^{* * *}$ \\
\hline & $(0.174)$ & $(0.315)$ & $(0.237)$ \\
\hline \multirow[t]{2}{*}{ Sanctions $_{\mathrm{t}-1} *$ Single-party $_{\mathrm{t}-1}$} & -- & $-0.725 *$ & $-0.548 *$ \\
\hline & & $(0.391)$ & $(0.327)$ \\
\hline \multirow[t]{2}{*}{ Sanctions $_{\mathrm{t}-1}{ }^{*}$ Military $_{\mathrm{t}-1}$} & -- & $-0.870 * *$ & $-0.747 *$ \\
\hline & & $(0.442)$ & $(0.423)$ \\
\hline \multirow[t]{2}{*}{ Single-party regime ${ }_{t-1}$} & -0.264 & -0.171 & -0.175 \\
\hline & $(0.175)$ & $(0.183)$ & $(0.190)$ \\
\hline \multirow[t]{2}{*}{ Military regime ${ }_{\mathrm{t}-1}$} & 0.222 & $0.389 *$ & $0.435^{*}$ \\
\hline & $(0.208)$ & $(0.217)$ & $(0.240)$ \\
\hline \multirow[t]{2}{*}{ GDP per capita $(\log )_{t-1}$} & -0.134 & -0.121 & -0.084 \\
\hline & $(0.123)$ & $(0.126)$ & $(0.128)$ \\
\hline \multirow[t]{2}{*}{ Foreign aid $(\log )_{t-2}$} & 0.056 & 0.059 & -- \\
\hline & $(0.065)$ & $(0.063)$ & \\
\hline \multirow[t]{2}{*}{ Trade openness ${ }_{t-2}$} & -0.001 & -0.001 & -- \\
\hline & $(0.001)$ & $(0.001)$ & \\
\hline \multirow[t]{2}{*}{ Foreign aid $(\log )_{t-1}$} & -- & -- & 0.089 \\
\hline & & & $(0.072)$ \\
\hline \multirow[t]{2}{*}{ Trade openness ${ }_{t-1}$} & -- & -- & $-0.007 * * *$ \\
\hline & & & $(0.002)$ \\
\hline \multirow[t]{2}{*}{ Economic growth ${ }_{\mathrm{t}-1}$} & -0.220 & -0.107 & -0.503 \\
\hline & $(0.941)$ & $(0.970)$ & $(0.923)$ \\
\hline \multirow{2}{*}{ Cold War ${ }_{t-1}$} & -0.171 & -0.149 & -0.164 \\
\hline & $(0.144)$ & $(0.145)$ & $(0.140)$ \\
\hline \multirow[t]{2}{*}{ Population $(\log )_{t-1}$} & $0.256 * * *$ & $0.259 * * *$ & $0.222^{* * *}$ \\
\hline & $(0.069)$ & $(0.066)$ & $(0.065)$ \\
\hline \multirow[t]{2}{*}{ Colony before ${ }_{t-1}$} & $-0.668^{* * *}$ & $-0.693 * * *$ & $-0.680 * * *$ \\
\hline & $(0.198)$ & $(0.200)$ & $(0.194)$ \\
\hline \multirow[t]{2}{*}{ Ethnic fractionalization ${ }_{\mathrm{t}-1}$} & 0.333 & 0.346 & 0.327 \\
\hline & $(0.279)$ & $(0.267)$ & $(0.273)$ \\
\hline \multirow[t]{2}{*}{ Muslim population (\%) ${ }_{\mathrm{t}-1}$} & 0.001 & 0.001 & 0.002 \\
\hline & $(0.001)$ & $(0.001)$ & $(0.001)$ \\
\hline \multirow[t]{2}{*}{ Interstate war ${ }_{\mathrm{t}-1}$} & -0.244 & -0.252 & -0.080 \\
\hline & $(0.359)$ & $(0.372)$ & $(0.303)$ \\
\hline \multirow[t]{2}{*}{ Intrastate war ${ }_{\mathrm{t}-1}$} & $1.10 * * *$ & $1.10^{* * *}$ & $1.02 * * *$ \\
\hline & $(0.191)$ & $(0.190)$ & $(0.196)$ \\
\hline \multirow[t]{2}{*}{ Internationalized internal conflict ${ }_{\mathrm{t}-1}$} & $2.03 * * *$ & $2.05^{* * *}$ & $2.11^{* * *}$ \\
\hline & $(0.546)$ & $(0.554)$ & $(0.456)$ \\
\hline Observations & 1265 & 1265 & 1298 \\
\hline Log pseudolikelihood & -1166.16 & -1163.89 & -1196.59 \\
\hline Pseudo- $\mathrm{R}^{2}$ & 0.3490 & 0.3503 & 0.3495 \\
\hline$\beta$ Sanctions $+\beta$ (Sanctions*Single-party) & -- & $0.426 * *$ & $0.592 * * *$ \\
\hline$\beta$ Sanctions $+\beta($ Sanctions $*$ Military) & -- & 0.281 & 0.394 \\
\hline
\end{tabular}


The inclusion of the one-year lags of aid and trade instead of the two-year lags does not much affect the results, so the basic patterns identified hold. In this specification, apart from the significant and negative effect of trade on repression - which is consistent with Hafner-Burton's (2005) previous findings - we can also observe that the impacts of sanctions under single-party and military regimes are slightly stronger than in model 2. The other control variables perform in general as in other comparative studies of repression. Wars increase repression, particularly those that begin as internal conflicts. The size of the country's population is also an important determinant of terror levels. Regime type is also found to matter; on average, military regimes rely more on terror than the other two forms of authoritarianism. The previous regime matters, too; regimes in countries that emerged after decolonization were much less repressive on average.

In sum, the results offered so far conform well to our proposed hypotheses. Thus, as expected, the highest increases in repression levels are found in those regimes whose capacity to buy off support is most harmed by the imposition of sanctions, namely, personalist regimes. Such a "brutal" response needs to be understood, then, as a last resort. Furthermore, our findings suggests that any difference observed between broader regime categories (that is, democracies vs. dictatorships) in repression levels as a response to sanctions is mainly driven, for the case of non-democracies, by the strong effect found in personalist regimes and to a lesser extent in singleparty regimes.

\section{Concluding Remarks}

Economic sanctions, probably the most widely known form of foreign pressure, seek to generate a policy or institutional change in the targeted countries by imposing costs on them. Yet, when applied to authoritarian governments, they are more likely to trigger domestic policy changes aimed at maximizing rulers' likelihood of retaining office. Concretely, authoritarian rulers modify their levels of rewards for loyalty and of repression. These reactions, we argue, depend on the type of regime and the extent to which sanctions hurt countries' revenues.

Using data on public spending, spending composition and repression, we have shown that there are significant differences across regimes in the strategies adopted to react to the economic constraints and political challenges posed by economic sanctions. Specifically, we argue that sanctions may cause an increase in the price of loyalty to the regime and an increase in the price of repression. This calls for a response from the regime authorities in order to avoid the destabilization of the incumbent government. 
Empirically, we have shown that sanctions are related to sharp decreases in the amount of public spending under personalist regimes, which are precisely those whose revenue sources (aid and trade) are more damaged by external coercive measures. Unable to continue bribing and rewarding its key supporters, the only option left for this sort of dictator consists in substantially increasing repression levels.

Single-party regimes increase the amount of goods delivered to their support groups. This means that these regimes, relying as they do on broader sectors of the society, increase the share of public resources devoted to subsidies and transfers. At the same time, repression levels increase as well, but to a smaller extent than under personalist regimes. Finally, military regimes show a different pattern. They share with single-party cases the need to increase the rewards to the members of the support coalition, and hence they increase expenditures on goods and services which in turn translate in higher wages and salaries and higher military spending. Yet these regimes increase repression levels only slightly (and not significantly), and reduce public services (subsidies and transfers).

Are these responses useful? Escribà-Folch and Wright (forthcoming) find that in fact sanctions are associated with greater ruler instability only in personalist regimes, while they are largely ineffective for leaders in single-party and military regimes. This reveals that the costs imposed by sanctions on the patronage resources available to personalist rulers affect their prospects of retaining power.

\section{References}

Allen, Susan Hannah. 2008. The Domestic Political Costs of Economic Sanctions. Journal of Conflict Resolution, 52 (6): 916 $\$ 944$.

Bates, Robert H. 2008. When Things Fell Apart. State Failure in Late-Century Africa. New York: Cambridge University Press.

Brooks, Risa A. 2002. Sanctions and Regime Type: What Works, and When? Security Studies, 11 (4): $1 \$ 50$.

Brough, Wayne T. and Mwangi S. Kimenyi. 1986. On the Inefficient Extraction of Rents by Dictators. Public Choice, 48 (1): 37-48.

Brownlee, Jason. 2007. Authoritarianism in an Age of Democratization. New York: Cambridge University Press.

Bueno de Mesquita, Bruce, James D. Morrow, Randolph M. Siverson, and Alastair Smith. 2003. The Logic of Political Survival. Cambridge, Mass.: MIT Press.

Collier, Paul and Anke Hoeffler. 2007. Military Spending and the Risks of Coups d'Etat. Manuscript. Centre for the Study of African Economies, Department of Economics, Oxford University.

Dashti-Gibson, Jaleh, Patricia Davis, and Benjamin Radcliff. 1997. On the Determinants of the Success of Economic Sanctions: An Empirical Analysis. American 
Journal of Political Science 41 (2): 608-618.

Davenport, Christian. 2007. State Repression and the Tyrannical Peace. Journal of Peace Research, 44 (4): 485 $\$ 504$.

De Boef, Suzanna and Luke Keele. 2008. Taking Time Seriously. American Journal of Political Science, 52 (1): 184\$200.

Desai, Raj M., Anders Olofsgård, and Tarik M. Yousef. 2009. The Logic of Authoritarian Bargains. Economics and Politics, 21 (1): 93\$125.

Drezner, Daniel W. 1998. Conflict Expectations and the Paradox of Economic Coercion. International Studies Quarterly, 42 (4): 709 $\$ 731$.

Drury, A. Cooper. 1998. Revisiting economic sanctions reconsidered. Journal of Peace Research, 35 (4): 497\$509.

Escribà-Folch, Abel. 2009. Do Authoritarian Institutions Mobilize Economic Cooperation? Constitutional Political Economy, 20 (1): 71\$93.

Escribà-Folch, Abel and Joseph Wright. Forthcoming. Dealing with Tyranny: International Sanctions and the Survival of Authoritarian Rulers. International Studies Quarterly.

Gandhi, Jennifer and Adam Przeworski. 2006. Cooptation, Cooperation, and Rebellion under Dictatorships. Economics \& Politics, 18 (1): $1 \uparrow 26$.

Gandhi, Jennifer, and Adam Przeworski. 2007. Authoritarian Institutions and the Survival of Autocrats. Comparative Political Studies, 40 (11): 1279-1301.

Geddes, Barbara. 1999. What Do We Know about Democratization after Twenty Years? Annual Review of Political Science, 2: 115-144.

Geddes, Barbara. 2004. Authoritarian Breakdown. Manuscript, University of California, Los Angeles.

Gershenson, Dmitriy, and Herschel I. Grossman. 2001. Cooption and Repression in the Soviet Union. Economics \& Politics, 13 (1): 31-47.

Gibson, Clark C., and Barak Hoffman. 2002. Dictators with Empty Pockets: A Political Concessions Model of Africa's Democratization. Paper presented at the 2002 Annual Meetings of the American Political Science Association, September, Boston, Mass.

Gleditsch, Nils Petter, Peter Wallensteen, Mikael Eriksson Margareta Sollenberg, and Håvard Strand. 2002. Armed Conflict 1946-2001: A New Dataset. Journal of Peace Research, 39 (5): 615 $\$ 637$.

Gleditsch, Kristian S., and Michael D. Ward. 2006. Diffusion and the International Context of Democratization. International Organization, 60 (4): 911-933.

Hafner-Burton, Emilie M. 2005. Trading Human Rights: How Preferential Trade Agreements Influence Government Repression. International Organization, 59 (3): $593 \$ 629$.

Hafner-Burton, Emilie M., and Kiyoteru Tsutsui. 2007. Justice Lost! The Failure of International Human Rights Law to Matter Where Needed Most. Journal of Peace Research, 44 (4): 407-425.

Hufbauer, Gary C., Jeffrey J. Schott, Kimberley A. Elliott, and Barbara Oegg. 2007. Economic Sanctions Reconsidered. Washington, DC: Peterson Institute for International Economics.

Jackson, Robert H., and Carl G. Rosberg. 1984. Personal Rule: Theory and Practice in Africa. Comparative Politics, 16 (4): 421-442.

Kaempfer, William H., and Anton D. Lowenberg. 1988. The Theory of International 
Economic Sanctions: A Public Choice Approach. The American Economic Review, 78 (4): 786-793.

Kaempfer, William H. and Anton D. Lowenberg. 1992. International Economic Sanctions: A Public Choice Perspective. Boulder, CO: Westview Press.

Kaempfer, William H., Anton D. Lowenberg and William Mertens. 2004. International Economic Sanctions against a Dictator. Economics \& Politics, 16 (1): 29-51.

Kenny, Lawrence W. and Stanley L. Winer. 2001. Tax Systems in the World: An Empirical Investigation into the Importance of Tax Bases, Collection Costs, and Political Regime. Carleton Economic Working Paper No. 01-03.

Kirshner, Jonathan. 1997. The Microfoundations of Economic Sanctions. Security Studies, 6 (3): $32 \pm 64$.

Lacy, Dean and Emerson M. S. Niou. 2004. A Theory of Economic Sanctions and Issue Linkage: The Roles of Preferences, Information, and Threats. Journal of Politics, 66 (1): $25 \$ 42$.

Lebovic, James H. and Erik Voeten. 2009. The Cost of Shame: International Organizations and Foreign Aid in the Punishing of Human Rights Violators. Journal of Peace Research, 46 (1): 79₫97.

Lektzian, David, and Mark Souva. 2007. An Institutional Theory of Sanctions Onset and Success. Journal of Conflict Resolution, 51 (6): 848-871.

Maddison, Angus. 2006. World Population, GDP and Per Capita GDP, 1-2003 AD. Available at: http://ggdc.net/maddison/

Mahdavi, Saeid. 2004. Shifts in the Composition of Government Spending in Response to External Debt Burden. World Development, 32 (7): 1139\$1157.

Marinov, Nikolay. 2005. Do Sanctions Destabilize Country leaders? American Journal of Political Science, 49 (3): 564-576.

Niblock, Tim. 2001. Pariah States and Sanctions in the Middle East: Iraq, Libya, Sudan. Boulder, CO: Lynne Rienner.

Nooruddin, Irfan. 2002. Modeling Selection Bias in Studies of Sanctions Efficacy. International Interactions, 28 (1): 59475.

Olson, Robert S. 1979. Economic Coercion in World Politics: With a Focus on NorthSouth Relations. World Politics, 31 (4): 471-494.

Pape, Robert A. 1997. Why Economic Sanctions Do Not Work. International Security, 22 (2): 90\$136.

Peksen, Dursun. 2009. Better or Worse? The Effect of Economic Sanctions on Human Rights. Journal of Peace Research, 46 (1): 59\$77.

Poe, Steven C. and C. Neal Tate. 1994. Repression of the Human Right to Personal Integrity in 1980s: A Global Analysis. American Political Science Review, 88 (4): $853 \$ 872$.

Poe, Steven C., C. Neal Tate and Linda Camp Keith. 1999. Repression of the Human Right to Personal Integrity Revisited: A Global Cross-National Study Covering the Years 1976-1993. International Studies Quarterly, 43 (2): 291\$313.

Rodrik, Dani. 1998. Why Do More Open Economies Have Bigger Governments? Journal of Political Economy, 106 (5): 997\$1032.

Ross, Michael. 2008. Oil, Islam, and Women. American Political Science Review, 102 (1):107-123.

Smith, Benjamin. 2004. Oil Wealth and Regime Survival in the Developing World, 1960-1999. American Journal of Political Science, 48 (2): 232-246.

Smith, Benjamin. 2005. Life of the Party. The Origins of Regime Breakdown and Per- 
sistence under Single-Party Rule. World Politics, 57 (3): 421-451.

Strand, Havard, Joachim Carlsen, Nils Petter Gleditsch, Havard Hegre, Christin Ormhaug, and Lars Wilhelmsen. 2005. Armed Conflict Dataset Codebook Version 3-2005. Oslo: International Peace Research Institute. Available at http://www.prio.no/CSCW/Datasets/Armed-Conflict/ (Accessed April 2008).

Tanzi, Vito and Hamid R. Davoodi. 1997. Corruption, Public Investment, and Growth. IMF Working Paper No 97/139.

Tsebelis, George. 1990. Are Sanctions Effective? A Game-Theoretic Analysis. Journal of Conflict Resolution, 34 (1): 3\$28.

Ulfelder, Jay. 2005. Contentious Collective Action and the Breakdown of Authoritarian Regimes. International Political Science Review, 26 (3): 311-334.

Ulfelder, Jay. 2007. Natural-resource Wealth and the Survival of Autocracy. Comparative Political Studies, 40 (8): 995-1018.

Van de Walle, Nicolas. 2001. African Economies and the Politics of Permanent Crisis, 1979-1999. Cambridge, UK: Cambridge University Press.

Weiss, Thomas G., David Cortright, George A. Lopez, and Larry Minear (eds). 1997. Political Gain and Civilian Pain: Humanitarian Impacts of Economic Sanctions. Lanham, Maryland: Rowman and Littlefield.

Wintrobe, Ronald. 1990. The Tinpot and the Totalitarian: An Economic Theory of Dictatorship. The American Political Science Review, 84 (3): 849-872.

Wintrobe, Ronald. 1998. The Political Economy of Dictatorship. New York: Cambridge University Press.

Wood, Reed M. 2008. A Hand upon the Throat of the Nation: Economic Sanctions and State Repression, 1976-2001. International Studies Quarterly, 52 (3): $489 \uparrow 513$.

Wright, Joseph. 2007. Foreign Aid and Political Regimes. Ph.D. diss., Department of Political Science, UCLA. 
